\title{
PROBLEMS OF HEMISPHERIC DEFENSE
}


Committee on International Relations NORTHERN SECTION

T. H. Goodspeed, Chairman; A. C. Blajsdell, J. B. Condliffe, B. H. Crocheron, H. I. Priestley,

F. M. Russell; F. C. Stevens, Secretary 


\section{PROBLEMS \\ OF HEMISPHERIC DEFENSE}

LECTURES DELIVERED UNDER THE AUSPICES OF THE COMMITTEE ON INTERNATIONAL RELATIONS

ON THE BERKELEY CAMPUS OF THE

UNIVERSITY OF CALIFORNIA

AUTUMN I94I

UNIVERSITY OF CALIFORNIA PRESS

BERKELEY AND LOS ANGELES

r942 


\section{UNIVERSITY OF CALIFORNIA PRESS \\ BERKELEY, CALIFORNIA}

\section{CAMBRIDGE UNIVERSITY PRESS}

LONDON, ENGLAND

$$
\text { COPYRIGKT, 1942, BY }
$$

THE REGENTS OF THE UNIVERSITY OF CALIFORNIA

Price: Cloth, \$1.50; Paper, \$1.00 